\title{
How to Cross Cultural Borders While Discussing National Literature Internationally
}

\begin{abstract}
In this article, various intercultural connections of Polish literature, considered to be a "minor" literature, are explored in order to situate it within a European context and demonstrate how Polish literature has functioned outside the national context. The article focuses on three possible ways of introducing foreign readers to Polish literature: by discussing texts that were originally written by Polish (and bilingual) authors in “major” languages, by interpreting world-literature texts that are intertextually connected with Polish ones and/or their authors, and by the comparative analysis of translations that have been produced by different translators of Polish literature working in different parts of the world. "Minor"-literature strategies are connected with the need to adopt widely read languages, which is often driven by mechanisms of the World Republic of Letters as described by Pascale Casanova. When "minor" literary authors/works establish themselves internationally, they enter other literatures and produce intercultural intertextuality. Translations play a crucial role in the above-mentioned processes, and they can serve as tools for comprehensive understanding and interpretation, which will also be explored in depth in order to add a currently missing element to our knowledge of what European literature is, and how particular European literatures contribute to it.
\end{abstract}

Keywords: European literature, global literature, intertextuality, Polish literature, translation

In this article, I will present possible ways of crossing cultural borders in the context of a one-volume English-language history of Polish literature that I am currently working on. The compendium addresses both foreign and Polish readers, and presents traditional forms, genres, and themes of Polish literature, as well as new forms which have been developing in the multicultural world and also on the multicultural internet. The balance between tradition and (post)modernity, local and global, will enable foreign readers to acquire some perspective on one of the relatively less well-known European literatures, whereas domestic readers will be able to see their own well-known literature from different cultural angles.

While being a European literature in its own eyes, Polish literature is usually described by outsiders as being one of the Eastern European (or East-Central Eur- 
opean) literatures. Such umbrella terms not only deprive it of its individual features but also of the Western European and transatlantic connections which have always been important for its development (Skwara 2015, 222-228). Therefore, I find it important to emphasize the various intercultural connections of Polish literature. This will help to situate it within a European context and demonstrate how Polish literature has functioned outside the national context, adding a missing element to our knowledge of what European literature is and how particular European literatures contribute to it. Here, I will focus on three possible ways of introducing foreign readers to Polish literature: by discussing texts that were originally written by Polish (and bilingual) authors in "major” languages; by interpreting world-literature texts that are intertextually connected with Polish ones and/or their authors; and, last but not least, by comparative analysis of translations that have been produced by translators of Polish literature working in different parts of the world. These three exemplary ways of crossing cultural borders by "minor"-literature authors are connected with a well-known process that shapes world literature - the need to adopt widely read languages. As I will demonstrate, it is not limited to authors with immigrant background and it is often driven by mechanisms of the World Republic of Letters as described by Pascale Casanova (notwithstanding the fact that the historical centres of the Republic change). In turn, literary authors/works that have established themselves internationally enter other literatures and produce intercultural intertextuality. Translations play a crucial role in the above-mentioned processes, and they can serve not only as transmitters of originals but also as tools for comprehensive understanding and interpretation, which I will also try to explore.

Obviously, translations are the key to understanding any foreign literature, and they determine the extent to which that literature, and its function in European/world literature, can be comprehended. Let me begin with an example:

Cinema Palace: killing in Bombay

ay ay ay ay ay ay ay ay

the sea a car four oaks

someone at a porter frowns

Ola Föns gets on my nerves

How awful a herring smells

A flea bit Hela's calf

How ugly his teeth are

Someone's stood over me and stands there

Aren't you afraid of God Sir

Sit down for God's sake I am calling

Mia May out of a window is falling

She is sure to lose her life 


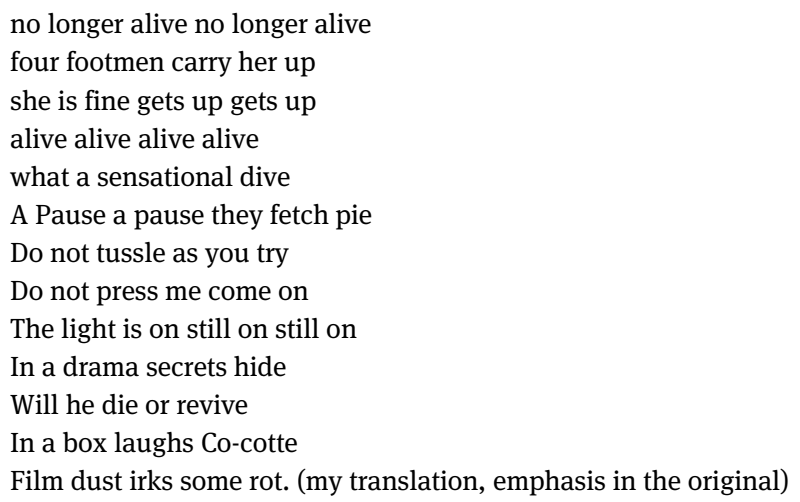

If an English-language reader read only the above poem, I doubt whether the culture of its origin would be easy to pinpoint. For specialists in the history of cinema, the names of the actresses might be a hint - but they would be hints about the epoch rather than about any particular literature/culture. As a matter of fact, it is a poem by Tytus Czyżewski, ${ }^{1}$ a versatile Polish avant-garde poet and painter, rather seldom known outside of Poland, whose early (1921) poem perceptively describes features of mass film culture which we still discuss today. In many respects, the poem is more global than local. Unfortunately, it was not translated, and thus it did not participate in global discussions on the intermediality of literature. I invoke the poem by Czyżewski not only because of its intercultural/intermedial potential but also because of the fact that its author, together with other Polish avant-garde poets of the time, was distinctly conscious of the significance of translation and the necessity of active participation in intercultural exchange. One could say that he was conscious of the rules of the World Republic of Letters long before Pascale Casanova formulated the concept. It was in collaboration

1 "Kino Palace: mord w Bombaju // aju aju aju aju / morze auto cztery drzewa / ktoś na portiera się gniewa / Ola Föns na nerwach gra mi / Jak tu strasznie czuć śledziami / Pchła ugryzła Helę w łydkę / Jakie on ma zęby brzydkie / Ktoś nade mną stanął stoi / Czy Pan Boga się nie boi / Na miły Bóg niech pan siada / Mia May z okna wypada / Ona pewnie się zabije // już nie żyje już nie żyje / czterej niosą ją lokaje / nic jej nie jest / wstaje wstaje / żyje żyje żyje żyje / co za sensacyjne chryje / Pauza pauza niosą ciasta / Niech pan zbytnio się nie szasta / Panie niech mnie pan nie gniecie / Bo jeszcze światło się świeci / Dramat tajemnice kryje / Czy on umrze czy ożyje / W loży śmieje się Ko-ko-ta / Film kurz nerwy trochę błota" (Czyżewski 2009, 81; emphasis in the original). My lineby-line translation may help foreign readers follow a digital adaptation of the original poem which is accessible online (http://ha.art.pl/czyzewski/sensacja_w_kinie.html. [22 April 2019]). The animated adaptation can also serve as an illustration of the second life of poetry nowadays in intermedial contexts. 
with other artists that Czyżewski established a bilingual art magazine, L'Art Contemporain/Sztuka Wspótczesna [Modern Art], in Paris in the late 1920s (19291930); it was meant to be read and perceived from within a cultural centre, as well as to participate on an equal basis in European cultural exchange. Each of the magazine's three issues included an introductory article entitled "Kilométrage" [Mileage] by Jan Brzękowski (1903-1983), in both French and Polish, a bilingual practice that applied to other content as well, such as essays on art and Polish and French poetry. While short-lived, the magazine's attempt to enter the European cultural stage is symptomatic of Polish writers' conscious effort to become a real part of European artistic and literary exchange. The editor of the magazine, Brzękowski, became a bilingual Polish poet whose poetry appeared in French and Polish until the late 1970s.

Bilingualism is not very common in Polish writers, particularly poets, for whom the Polish language has always been a unique tool. Yet I believe it is worth remembering some meaningful exceptions with readers both at home and abroad in mind: to introduce foreign readers to a literature which sometimes can be read in their own languages, and to familiarize readers at home with the forgotten cases of how international their own, apparently familiar, literature really is.

Apart from the Art Contemporain circle, French was used by Polish authors in a number of other cases. The first eminent one is a novel by an Enlightenment man of letters, Count Jan Potocki (1761-1815). Written at the beginning of the nineteenth century, when French was the recognized language of the European cultural centre, Manuscrit trouvé à Saragosse [The Saragossa Manuscript] is a masterpiece of narrative writing. Its author, a graduate of Lausanne and Geneva schools, spent most of his life either in Poland, Europe, or on exotic travels. His novel appeared at the beginning of the nineteenth century in both St Petersburg and Paris. Exceptionally, while Potocki was a Pole and played an active role at the Polish court and in the early parliamentary system (as well as at tsarist institutions after the partitions), he wrote only in French. His choice of language was motivated not only by his education, but also by the idea of a common Europe with a common language at a time when French seemed to be the lingua franca of the epoch. Still, Potocki's novel is not an ideological work, nor is it explicitly connected to either francophone or Polish culture. First and foremost, it is a highly sophisticated adventure narrative, relating the Spanish travels of a certain Alfons van Worden, who meets unusual people of different cultural backgrounds on his way to Madrid and has strange, often supernatural experiences. The people he meets narrate their stories, and the heroes of their stories tell their own, and so on, making the novel into a fine example of the "story within a story" technique that is also typical of the Thousand and One Nights tales. Its peculiar nature - it is the work of a Polish author written in French - meant that it functioned mostly on the 
peripheries of Polish culture, at least until it was adapted for the cinema by the famous Polish film director Wojciech Hass in the mid-1960s. Indeed, a revival of interest in the novel is underway at the moment. The modern critical editions and new scholarly interpretations based on the latest findings in French, Polish, Spanish, and Russian libraries have been published in France, while the first unabridged translation into Polish by Anna Wasilewska appeared in Poland (2015), as did the first online adaptation. ${ }^{2}$ Potocki's novel is a fine introduction to European Enlightenment culture with its search for universality and a transnational narrative. It can also be read, as French biographers and interpreters of Potocki put it, as "le dernier grand roman des Lumières européennes" [the last great novel of the European Enlightenment] (Rosset and Triaire 2004, 335; my translation). With Hass's masterful film adaptation, The Saragossa Manuscript, now digitally remastered under the auspices of Martin Scorsese and available in many languages, this intriguing example of international Polish writing may find new life in the changing cultural environment of a united Europe.

The French influence has many other eminent representatives among Polish authors, albeit in different historical and cultural contexts. In the nineteenth century, Adam Mickiewicz's work most obviously springs to mind. Simultaneously a political exile and professor of Slavonic literatures at the Collège de France in Paris, Poland's leading Romantic poet lectured in French in the early 1840s to an international audience not only on Slavonic literatures, or on the political and mystical issues which caused him to be later expelled from the position, but also on a wide range of academic interests that included world literature and philosophy. For instance, Mickiewicz included the essays of the American philosopher Ralph Waldo Emerson, completely unknown in continental Europe at the time, in his lectures in translation and (or) paraphrase, usually along with his own comments. Two of Emerson's essays ("History" and "Man the Reformer") later appeared separately in the magazine La Tribune des peuples [People's Tribune], which Mickiewicz edited. His versions of these essays are intriguing due to his daring attempt at finding his voice among three cultures: US, French, and Polish (Skwara 2004, 121-145). Mickiewicz's lectures, which also included many of his translations from Polish and other Slavonic literatures, were likewise later published in French and Polish translations on the basis of versions produced by copyists present during the lectures, and later revised by Mickiewicz. For those who do not read Polish, the French versions of Mickiewicz's lectures offer what is still a fascinating introduction to Slavonic literary cultures (and politics!).

2 http://haart.e-kei.pl/rekopis/00_intro.html(22 April 2019). 
Not only French was used by Polish writers. German also proved to be quite popular - the best-known modernist example of a Polish writer writing in both German and Polish is Stanisław Przybyszewski (1868-1927), the enfant terrible of the Young Poland period. Having studied at a German gymnasium in Torun (Thorn), he went to Berlin to study architecture. There, he engaged with Nietzsche's philosophy, Satanism, and the bohemian life, as well as beginning his literary career, publishing both psychological essays and literary works. ${ }^{3}$ Przybyszewski also prepared the Polish editions of his works, sometimes depending on fellow writer-translators, and composed long prose poems and dramas in Polish. One of his most famous works, the trilogy Homo Sapiens, was first published in Germany (1895-1896), where it was well received. Its Polish version was then published in Lwów (Lviv) at the turn of the nineteenth century and translated into English within the next decade. Przybyszewski's bilingualism has already been analysed in a monographic study, whose author claims that his original German texts are more interesting than the Polish versions since they are driven by a spirit of real creativity, while the latter are more like "recreations" (Łuczyński 1982, 7172). These works were also characterised by Przybyszewski's passionate struggle with language, which his friend, the German poet Richard Dehmel, played a helping hand in resolving. There is certainly more to explore in Przybyszewski's vast œuvre.

The tradition of Polish-German writing continued with emigrant writers during the 1980s, though on quite a different basis. Having found political asylum and economic support, they began writing in a new language to tell their life stories, which could not be published in Communist Poland for political reasons. This is the case with Christian Skrzyposzek (1943-1999), whose Wolna Trybuna [Free Tribune] was published in German translation by Olaf Kuhn as Freie Tribüne (1983), and then in the original Polish version as Wolna Trybuna in Berlin (1985) and finally Warsaw (1999). Skrzyposzek's bilingual work includes a now-lost autobiography, a play published in the theatre magazine Dialog in Poland in the 1960s, and Polish versions of his German texts. However, such work receded, in the end, in favour of writing in German. His last novel, Die Annonce [The Announcement] (2005), which was edited and published after his death in Germany, became a part of German literature as naturally as the works of Artur Becker. Dariusz Muszer (b. 1959) presents a different case, for he consistently translated his novels into Polish. The best-known examples - Die Freiheit riecht nach Vanille/Wolność pachnie

3 An example of the former is Zur Psychologie des Individuums: I. Chopin und Nietzsche; II. Ola Hansson (1892), whereas the latter are represented by Totenmess (1853), De Profundis (1895), Vigilien (1895), Homo Sapiens (1895-1896), and Satanskinder (1897), to name only a few examples. 
wanilia [Freedom Smells of Vanilla] (1999/2008) and Gottes Homepage/Homepage Boga [God's Homepage] (2003/2013) - were written in German and first published in Germany. Muszer fills the Polish versions of his novels with various hybrid language forms: creative translations of phrases and idioms, thought-provoking language calques, as well as various alienation effects. His Wolność pachnie wanilia also includes metalinguistic commentary, for instance: "Głupio pobiegło [dumm gelaufen], jak to mawiają w Niemczech, gdy chcą powiedzieć, że głupio wyszło” [It ran silly, as they say in Germany, when they want to say that something went wrong] (Muszer 2008, 29; my translation). The author also includes German words in the Polish lexical system and vice versa, with the conscious play on languages seen as a characteristic feature of his bilingual writing.

Another interesting example of a Polish-German writer, this time defined by a borderland context, is Piotr (Peter) Lachman (b. 1935), a poet, essayist, playwright, translator, and theatre director who was born before World War II into a German family in Gleiwitz, which became Gliwice - and part of Poland's territory - after the war. Gleiwitz/Gliwice had always had a bicultural character, and Lachman, who attended Polish schools there, continued to write in two languages despite leaving for Germany, where he spent most of his life. According to Przemysław Chojnowski, currently preparing a monograph on his "liminal" writing, Lachman is a model example of a man whose language and culture are typical of borderlands (Chojnowski, in press).

From the second half of the twentieth century onward, bilingual writing is dominated by Polish-English writing, possibly in connection with English becoming a global language. Here, just as in cases of Polish-German authors, self-translations and working in both languages are characteristic features. Stefan Themerson (1910-1988), a writer, poet, philosopher, photographer, filmmaker, and composer, is one of the most important and widely known Polish writers. Having started his brilliant career in Poland before World War II, he successfully continued it after the war in Great Britain. Besides Polish and English, he occasionally wrote in French, as well as translating some of his Polish works into English. His best-known work, the philosophical satire Wyktad Profesora Mmaa, was written in Polish in the 1940s, then self-translated into English and published in London as Professor Mmaa's Lecture in 1953 (with a foreword by Bertrand Russell). The novel enjoyed a worldwide career because of both its unusual idea (a professor giving a lecture on Homo sapiens to an audience of termites) and its linguistic and philosophical complexity. Of today's authors, Ewa Kuryluk (b. 1946) - an artist, art historian, and writer - has also translated her English texts into Polish (Grand Hotel Oriental, 1997) while continuing to write in English and, increasingly, in Polish as well.

Czesław Miłosz (1911-2004) was probably the most prestigious of Polish selftranslators into English, although it is difficult to identify him as the clear-cut 
author of his English poems, which were almost always written first in Polish (with a few exceptions, such as "To Raja Rao") and translated in cooperation with a native English speaker, most often Robert Hass. What seems more important in Miłosz's bilingual case, however, is his influential participation in the life of Englishlanguage, and especially US, literary and cultural circles. Miłosz not only met English-language readers and poets, conducted seminars on poetry, and wrote essays on literature in English, but also compiled an anthology of world poetry, A Book of Luminous Things (1996), which included Polish poems and had a slightly different Polish antecedent (Wypisy $z$ ksiag użytecznych [Excerpts from Useful Books], 1994). With its publication, Miłosz became the first Polish author to try to shape the world canon of poetry, or at least the first to play a leading, active role in such an endeavour. Up until then, Polish authors had not functioned in this manner in the World Republic of Letters, even when bilingual and/or bicultural. But Miłosz did, and he fully recognized that the Republic's language was no longer French, but English, thus switching into English (also aided by his long sojourn in the US) from his international debut in French (La prise du pouvoir [The Seizure of Power], 1953).

Miłosz's activities and English publications made him one of the most influential Polish poets in the US, to the point where he became a kind of hypotext for many American poems. In Robert Cording’s poem “Czeslaw Milosz’s Glasses,” a masterly balanced portrait of a great moral poet, for instance, Miłosz becomes something of a paragon for a generation of poets. Edward Hirsch's poem entitled "A Partial History of My Stupidity" (2008) is a good example of such a dialogue. It begins with the first line of the English version of Miłosz's poem "Rachunek" [Account] (1980) - "The history of my stupidity would fill many volumes," and alludes to its ending - "The history of my stupidity will not be written. / For one thing, it's late. And the truth is laborious" (trans. Miłosz and Pinsky; Miłosz 2001, 395). For a Polish reader, both Cording and Hirsch are intriguing examples of rereadings of Miłosz, who was perceived completely differently by a younger generation of Polish poets. In Poland, young poets had to overcome the shadow of the great poet, often by spectacular metaphoric annihilation. In the US, poets could simply refer to him without having to fight for their own position - Miłosz, a Noble Prize laureate (1980), was not as titanic a figure there as he was in Poland. These examples lead us to the second field of natural intercultural contexts for Polish literature, namely: intertextual references.

Bruno Schulz (1892-1942), a Polish author of Jewish origin who wrote in Polish (perhaps also in German, although no stories in German have survived), holds a special position in the field of intercultural intertextuality. We can even talk about a Schulz-derived literature, that is, novels which allude to his writing and tell his life story, or rather his after-life story, as is the case in novels by Dawid Grossman or Cynthia Ozick. Each of the (to date) six Schulz-derived novels - Clepsidra by Danilo 
Kiš (1972), See Under: Love by Dawid Grossman (first published in Hebrew as [Ayen Erekh: Ahavah], 1986), The Messiah of Stockholm by Cynthia Ozick (1987), The Prague Orgy by Philip Roth (1985), Tree of Codes by Jonathan Safran Foer (2010), and Un nomo che forse si chiamava Schulz [A Man Who Was Perhaps Called Schulz] by Ugo Riccarelli (2012) - contains various intertextual references to Schulz's two collections of short stories, Sklepy cynamonowe [The Cinnamon Shops] and Sanatorium pod Klepsydra [Under the Sign of the Hourglass]. The novels can also reshape his text, as Foer's Tree of Codes does. Foer literally carved out a new story by removing words from his favourite book to which he had earlier written a foreword (Bruno Schulz's Street of Crocodiles, 2008). All the words in the new book are still Schulz's (or rather those of his translator into English, Celina Wieniawska), but the book itself is by Foer. In this way, a sculptural object came into existence, as the publisher, Visual Editions, claims. ${ }^{4}$ Foer's artistic endeavour has already been analysed many times and from different angles, and even adapted for the stage; it has, not surprisingly, been appreciated more as an art object than as a literary text.

The phenomenon of raising Schulz's stories to the level of a widely recognized hypotext has its roots in his deeply symbolic and metaphoric writing, which can be read as a parable for life and an archetypal search for its meaning. His own tragic death - being shot by a German Nazi officer in his native Drohobycz in 1942 (in revenge for shooting the officer's "Jewish slave") - made him a painful example of a Holocaust victim, which increased his literary popularity. The other famous example of a Polish writer who himself became a hypotext is Witold Gombrowicz (1904-1969), one of the pre-eminent figures of Polish modernist literature. After spending much of his adult life in Argentina, to which he came just before the outbreak of World War II, Gombrowicz began to write in Spanish. He prepared the Spanish-language editions of some of his works, including his Diary, which differs considerably from the Polish version. Most significantly, Diario argentino is supplemented by new entries on Argentina, which creates a kind of heterotopia, a place where many cultures and spaces exist at the same time. Silvana Mandolessi carefully interprets this phenomenon, wondering whether Gombrowicz became part of Argentinian literature (Mandolessi 2011, 245-261). He certainly became an unusual member of Argentinian literary and artistic circles; some details are mentioned in his Spanish correspondence with Goma, for example. Gombrowicz also became a hypotext for Argentinian writers. He appeared, for instance, in Ricardo Piglia's Respiración artificial [Artificial Breathing] (1980) and Luis Martin's Las cartas profanes [Profane Letters] (2008) as a European intellec-

4 See https://en.wikipedia.org/wiki/Tree_of_Codes (22 April 2019). 
tual - escritor extranjero "foreign writer" - a partner in the ongoing discussions about Argentina and the world (see Gendaj 2012, 224-229). On the other hand, the same Gombrowicz became a paragon of avant-garde writing in Norwegian culture, especially for Dag Solstad, who in his novel Irr! Grønt! [Patina! Green!] (1969) makes various references to Gombrowicz's version of the Bildungsroman Fredydurke (1937). Solstad's main hero is a pendant of Gombrowicz's Józio, and the climax of his novel is a "duel fought with faces" - Gombrowicz's typical metaphor of a psychological struggle for one's own position in life.

There are also more exotic references to Polish novels, especially to Quo vadis, a classic on the life of early Christians in Rome written by Henryk Sienkiewicz, who received the Noble Price for his epic achievements in 1905. Koichi Kuyama has studied Japanese translations and adaptations of the novel (twenty-seven in total) and carefully analysed various references to it in six Japanese novels, including Hideyoshi and Rikyu by Nogami Yeako (1962-1963), that he considers to be adaptations of the Polish text to incorporate the realities of medieval Japan (Kuyama 2012, 44). Sienkiewicz’s novel even influenced, as Kuyama claims, the Japanese language, where "Quo vadis" - an abbreviation of "Quo vadis, Domine?", the question asked by St Peter on the road to Rome - became a popular saying. In South Korea, another Polish Noble laureate - Wisława Szymborska (19232012) - made her name as a universal philosophical poet oft-quoted by Korean critics, essayists, writers, singers, and even social and political commentators. Choi Sung Eun (Estera Czoj), a Korean scholar and translator of Polish, believes that this widespread reception was boosted by the fact that "this poetry contains elements that are close to our mentality and the philosophy of the East" (2014, 221; my translation). A collection of Szymborska's poetry was published by Munji, one of the biggest Korean publishers, as part of a prestigious series called "World Literature Daesan," and soon became a steady seller which entered the culture of the Far East in many different ways. Films alluding to her texts appeared in, for example, the Hong Kong production Turn Left, Turn Right (2003), which uses a motto from Szymborska's poem, or a film by the Korean director Min Kyu Dong entitled Kkeut-kwa sijak [The End and the Beginning] (2009), which is the title of the Munji collection of Szymborska's poetry. Uniquely, a ballet performance, Sireul ilneun sigan [Time for Poetry] (2010), based on eight of Szymborska's poems, was prepared by the Chang Sun Hee ballet ensemble and performed at the Seoul Arts Center in 2010 (Choi 2014, 208-209). This last example shows the unusual intermedial potential of Szymborska's poetry, which has been considered as universal by many European readers, and which has proved to be prone not only to intercultural but also to interemedial rereadings.

For foreign students/readers of literature, all these examples of Polish canonical writing that function intertextually in foreign languages and literatures have 
the potential to become a kind of introduction to Polish literature. For Polish readers, foreign references are usually a surprising and fascinating lesson on how their own literature entered world literature and is not as unknown or obscure as it is often claimed.

Although texts written in foreign languages by Polish authors, together with their intertextual (and intercultural) references, can make an interesting intercultural introduction to Polish literature, the full scope of the latter can be accessed only via translations. Since - as should not be forgotten - every translation is an interpretation, comparative translation analysis should be present in compendia on particular "minor" literatures. Typically, however, only one chosen translation is presented, due to practical reasons and lack of space. It is usually taken for granted, and only sporadically are some minor comments added; cf., for example, the latest compendium of Polish literature (Ten Centuries of Polish Literature, 2004). Yet there are differences between translations and commentaries on them, and these differences can enable foreign readers to access the complexities of the original meanings, sound patterns, and artistic forms. Domestic readers, on the other hand, can be confronted with the (often surprising) forms in which Polish texts reach the world. To give an example of how translation analysis could be included in a discourse on a national literary history, I will discuss a piece from early Polish poetry, namely our Renaissance jewel, Treny [Threnodies/Laments] by Jan Kochanowski.

The Treny were created at the peak of the Polish Renaissance (1580) and have occupied a central place in Polish poetry ever since. Devoted to the poet's late daughter Orszula, the cycle of nineteen poems went far beyond the literary conventions of the funeral literature of the epoch, both artistically and emotionally. Not only did the poet compose a masterfully shaped epicedium cycle on the death of a little girl, which was exceptional in European literature at the time, but he also inscribed elegiac topoi (artfully transferred from Latin into Polish) into his own existential experience. Since the Treny raise universal questions and express deep individual emotions, employing imagery, metaphors, and motifs important in Graeco-Roman and Biblical culture, they have often gained much attention and understanding outside Poland. The cycle has been commented on by scholars from all over the world in encyclopaedia articles and detailed analyses, and is usually described as the poet's greatest achievement. It has also attracted a number of translators. For instance, individual poems from the Treny have been translated into English nine times so far, and five translators have completed the whole cycle. Despite many obstacles, not least due to the peculiarity of early Polish modes of expression, sometimes not easily comprehensible even to modern Polish readers, the poetic art of the Treny seems to come across to a wide variety of readers. Whether we take a translation as an attempt to imitate the early Polish 
language (for example, the early nineteenth-century translation by John Bowring), or a modernized but faithful one (by Michał J. Mikoś), or a version liberated from verse and rhyme patterns (by Adam Czerniawski), or, finally, one composed by two famous poets from two cultures (by Stanisław Barańczak and Seamus Heaney, often regarded as the most poetic version), we find poetic texts that have attracted attention and a wide readership in new literary cultures.

The perfection of Kochanowski's poetic language - emphasized by the Romantic poetic titan Adam Mickiewicz during his lectures at the Collège de France in the early 1840 s - is based not only on concise phrases, sophisticated enjambments, idiomatic metaphors, and artfully constructed anaphors and periphrases or elaborate similes, but also on the unique sense of a new literary language and its ability to express human experience in a new cultural context. For the first time, a typical epicedium scheme consisting of both laudatio (a praise of the dead, and a demonstration of the great significance of the loss) and comploratio (the lament itself, including consolation and exhortation) was used for mourning a little girl, the daughter of the poet.

The Treny begin with an invocation to "all lamentations" and "all sorrows," alluding to those once expressed by Heraclitus and Simonides, to help the poet deal with the acts of "niepobożna śmierć" [impious death - Petrarch's impia mors]. ${ }^{5}$ This initial disquieting expression returns in the fourth poem of the cycle. Talk of the "impious death" who "ravaged the poet's eyes" by making him see his little child die, introduces the existential and religious doubts of the poet and the deep emotional tone of the cycle. Ancient figures - Niobe, who turned to stone having seen her children die (referenced in Tren IV), or Persephone, who takes Kochanowski's daughter to the underworld (Treny II, IV, V) - are used to create scenes of death and mourning based on ancient images. Yet the most dramatic question is addressed to Christian religious beliefs. Before we find this question in Tren X, the poet paints a picture of his cheerful daughter, unique and lovable, calling her the "Sappho of the Slavs" (despite her being under three years of age) but also a droga szczebiotka. The latter is a particularly tender expression, never translated successfully, which stands for a sweet, darling, talkative creature, a joy to her parents.

Tren X, especially popular among Polish readers, ${ }^{6}$ expresses the poet and suffering father's deepest doubts. They are introduced by questions about where his daughter might have gone. Both ancient mythical places (the Fortunate Isles, Charon's disconsolate lakes, far lands, celestial spheres) and Christian imagery

5 Translations from the Treny in this paragraph are my own.

6 Stefan Żeromski, a twentieth-century writer, describes in his essays (Snobizm i postęp [1929, 20]) a simple shoemaker reciting this poem at his work. 
(Heaven, Paradise, Purgatory) are hesitantly invoked, before the poet reaches a final sceptical conclusion and formulates a plea:

Gdzieśkolwiek jest, jeśliś jest, lituj mej żałości,

A nie możesz li w onej dawnej swej całości,

Pociesz mię, jako możesz, a staw się przede mną,

Lubo snem, lubo cieniem, lub marą nikczemną! (Kochanowski 1972, 19)

As the translations clearly show, it is difficult to interpret these seemingly simple lines with their masterly rhythm and rhymes, lines in which both the grief and the religious doubts reach a climax. The suffering father urges his daughter "wherever she is, if she is" (my rendition) to pity him and appear before his eyes in any form if her former self is lost. Mikoś's interpretation, the most faithful to the original when it comes to both verse form and to meaning, uses English which sounds slightly strange and loses some of the refinement of the original:

Wherever you are if you are, pity my dole,

And if you are not able as your former whole,

Console me, as you can, and make an appearance

As a dream, a shade, or an illusory substance. (Kochanowski, trans. Mikoś 1995b, 49)

Czerniawski, after earlier attempts, finally produced a completely modern and almost shockingly simple version (2001):

Wherever you are, if you are, take pity on my grief.

And if you cannot in the flesh

Console me and appear

As dream, shade or vision! (Kochanowski, trans. Czerniawski 2001, 43)

Barańczak and Heaney, with their characteristic "fluidity of verse" (Bogdan Czaykowski's expression) produced a highly poetical rendition that does, however, depart from the original:

Wherever you may be - if you exist -

Take pity on my grief. O presence missed,

Comfort me, haunt me, you whom I have lost,

Come back again, be shadow, dream or ghost. (Kochanowski, trans. Barańczak and Heaney 1995a, 21)

The poets take liberties here with the original shape of Kochanowski's verses, and also with some words and expressions. The word "ghost" for mara nikczemna (which might be rendered as "poor apparition") may seem stereotypical, especially when combined with the verb "haunt," whereas the phrase "If you exist" for jeśliś jest (literally "if you are”) loses the simplicity, artistic repetition, and soft re- 
peated sibilants of the original: gdzieśkolwiek jest jeśliś jest. One should note that this very formulation, often omitted by early translators but emphasized by more modern ones ("If you exist at all, pity my grief," reads Jerzy Peterkiewicz's translation [Kochanowski 1970]), is the pious poet's most drastic expression of doubt in the whole cycle.

To conclude, it should, I believe, be emphasized that a perception of any foreign literature, especially a "minor" one, depends on translations, and that there are always different possible ways of translating any literary work. Comparative analysis, for which there is usually no place in a narrative on literary history, has the potential to restore readers' attentiveness to the nature of texts that they can read only in translation.

Each of the three possible ways of introducing readers to Polish literature and enriching knowledge of it that I have described above has its own function. The texts written in "major" European languages can be seen as a gesture of invitation made by a "minor" literature to the wider world. They are also an attempt to provide that world with a direct access point to another culture. After all, as Mickiewicz claimed in his Paris lectures delivered in French and infused with his Emersonian intuition and English quotations, the term Stowianie "Slavs" comes from the word stowo, meaning "word.” Presentation and discussion of European/world texts that are intertextually connected with Polish ones can demonstrate the multicultural dimension of a literature that has too easily been labelled as "Eastern European," with various unfortunate consequences and limitations. Analysis of translations produced by various translators can, by contrast, reveal a variety of existing interpretative possibilities but also protect readers from misunderstandings arising from interpreting only interpretations (i.e. translations). I believe that the propositions presented above address not only the question of the presentation of one "minor" literature on a global literary history market, but also a wider question of the possible methods and tools that may be applied to any national discourse of literary history. Unless we stop seeing European/world literatures as single entities (or only chosen entities) which are not interconnected, we will not be able to see what European/world literature is and how it has been shaped over the ages.

\section{Works cited}

Borkowska, Grażyna, et al. Ten Centuries of Polish Literature. Trans. Daniel Sax. Warsaw: Instytut Badań Literackich PAN, 2004.

Choi, Sung Eun [Czoj, Estera]. “Recepcja poezji Wisławy Szymborskiej w Korei Południowej.” Pamiętnik Literacki 105.4 (2014): 195-211. 
Chojnowski, Przemysław. Liminalność i bycie pomiędzy w twórczości Petera/Piotra Lachmanna:

Studium literacko-kulturowe. Cracow: Universitas TAiWPN. In press.

Czyżewski, Tytus. Wiersze i utwory teatralne. Gdańsk: słowo/obraz terytoria, 2009.

Gendaj, Natalia. "Gombrowicz polityczny? Miejsce pisarza w literaturze argentyńskiej." Oblicza

światowości. Ed. Romuald Cudak. Katowice: Uniwersytet Śląski: Wydawnictwo Gnome,

2012. 220-231.

Kochanowski, Jan. “Tren X." Five Centuries of Polish Poetry 1450-1970. Ed. Jerzy Peterkiewicz and

Burns Singer. London: Oxford University Press, 1970. 6.

Kochanowski, Jan. Treny. Ed. Janusz Pelc. Wrocław: Zakład Narodowy im. Ossolińskich, 1972.

Kochanowski, Jan. Laments. Trans. Seamus Heaney and Stanistaw Barańczak. London: Faber and

Faber, 1995a.

Kochanowski, Jan. Treny: Laments. Trans. Michael J. Mikoś. Warsaw: Constans, 1995b.

Kochanowski, Jan. Treny: The Laments of Kochanowski. Trans. Adam Czerniawski. Ed. Piotr

Wilczek. Oxford: Legenda, 2001.

Kuyama, Koichi. “Quo vadis w Japonii - konteksty recepcyjne.” Oblicza światowości. Ed.

Romuald Cudak. Katowice: Uniwersytet Śląski. Wydawnictwo Gnome, 2012. 30-46.

Łuczyński, Krzysztof. Dwujęzyczna twórczość Stanisława Przybyszewskiego 1892-1900. Kielce:

Wydawnictwo Wyższej Szkoły Pedagogicznej w Kielcach, 1982.

Mandolessi, Silvana. "Heterotopia i literatura narodowa w Dzienniku argentyńskim Witolda

Gombrowicza.” Trans. Natalia Gendaj. Rocznik Komparatystyczny 2.2 (2011): 245-261.

Miłosz, Czesław. New and Collected Poems 1931-2001. New York: Ecco Press, 2001.

Muszer, Dariusz. Wolność pachnie wanilią. Szczecin: Wydawnictwo Forma. Stowarzyszenie

Literackie Forma, 2008.

Rosset, François, and Dominique Triaire. Jean Potocki: Biographie. Paris: Flammarion, 2004.

Skwara, Marta. Krąg transcendentalistów amerykańskich w literaturze polskiej XIX i XX wieku:

Dzieje recepcji, idei i powinowactw z wyboru. Szczecin: Wydawnictwo Uniwersytetu Szcze-

cińskiego, 2004.

Skwara, Marta. "Between 'Minor' and 'Major': The Case of Polish Literature.” Major versus Minor?

Languages and Literatures in a Globalized World. Ed. Theo D'Haen, Iannis Goerlandt, and

Roger D. Sell. Amsterdam and Philadelphia: John Benjamins, 2015. 221-231.

Żeromski, Stefan. Snobizm i postęp. Warsaw: Wydawnictwo Jakuba Mortkowicza, 1929.

Marta Skwara is a professor of Polish and Comparative Literature at the University of Szczecin, and has been the head of its comparative unit since 2005. She is the editor-in-chief of the Comparative Yearbook/Rocznik Komaratystyczny/Komparatistisches Jahrbuch. Her research interests include comparative literature, particularly reception and translation studies, and intertextuality. 
